\title{
Co- Relation of Ageless Glow Skin, and Traces the Evolution of Various "Second Chance"
}

\author{
Rahul Hajare* \\ Post Doc Scholar, Nagpur University, India
}

Submission: June 06, 2018; Published: June 14, 2018

*Corresponding author: Rahul Hajare, PG M.Pharm Scholar, Nagpur University, Nagpur, India, Tel: 9921707584; Email: rahulhajare17@gmail.com

\section{Abstract}

The truth has, most of today's top-selling, celebrity-endorsed anti-aging serums have stuffed with potentially toxic ingredients like parabens and phthalates, which have often hidden and not listed in safe formulas. Unknowingly, good folks from around the world have lathering these toxins all over their faces and bodies, which can result in a whole host of adverse effects. In a recent article published in the Washington Post, health columnist Jill Adams wrote, "Phthalates and parabens can interfere with the body's hormones, most notably reproductive hormones such as estrogen and testosterone. The possible health risks could include chronic diseases, cancers, and a host of developmental disorders and fertility problems." What has more; parabens appear to be potent inhibitors of mitochondrial function. The mitochondria have often described as the "powerhouses" of cells, as they are responsible for creating energy from the food and store. So now researcher know Ageless Glow is safe, but is it truly effective at overcoming the primary causes of aging skin?

a) The loss of collagen, which results in wrinkles and lines

b) A decrease of elastic fibers in connective tissue, which causes drooping and sagging skin

c) Sun damage and discoloration

d) Dehydration, which leaves the skin looking crepey, dry, and itchy

Keywords: Majestem; Senestem; Sodium Hyaluronate; squalane

\section{Introduction}

The secret to Ageless Glow has in its four breakthroughs, science-backed, natural ingredients, which help lift skin while reducing the visible signs of aging starting in just the first 7 days.

\section{Majestem - It Lifts Sagging Skin}

Majestem has an extract of Leontopodium alpinum a rare herb that grows on mountain ranges in the Pyrenees, the Alps, and the Himalayas. It has a rare and strictly protected plant, and because of its unique star-like appearance, it has often called The Queen of the Mountain. Traditionally, Edelweiss has been used in folk medicine to help control key biomarkers of aging, and recent research has shown that concentrated extracts possess powerful protective effects associated with signs of premature aging from sun exposure (i.e., photoaging) and more including

a) Providing visible face and neck lifting action

b) Tightening sagging neck skin

c) Lifting the cheeks

d) Smoothing out crow's feet wrinkles

e) Combatting against oxidative stress (e.g., pollution, UV radiation).
In a series of clinical studies, 34 women (ages 35 - 71), who presented visual signs of aging (like saggy skin on their necks and faces, swollen nose and crow's feet wrinkles), applied a cream containing 2\% Majestem (the same amount in Ageless Glow) twice daily on their faces and necks for 6 weeks. After just 3 weeks, the researchers found that sagging skin on the women's neck significantly tightened, sculpting and restoring a youthful neck line [1]. After 6 weeks, they found that the women's cheeks had been lifted and their tear troughs (i.e., "eye bags") had been reduced (Figures 1-4).

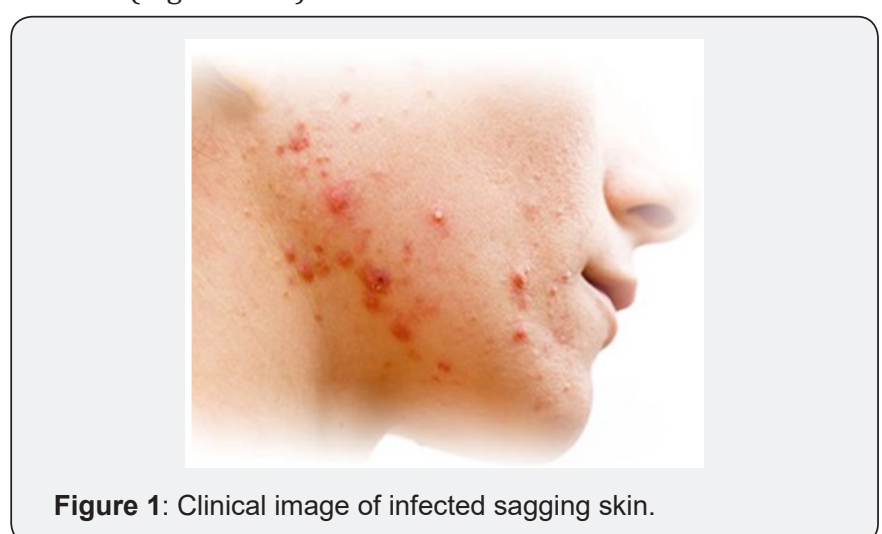




\section{Global Journal of Otolaryngology}

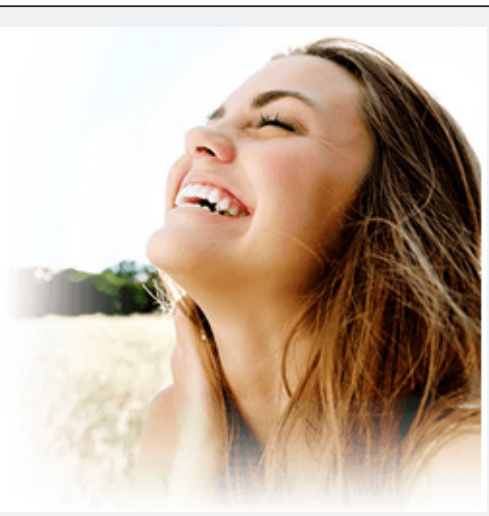

Figure 2: Majestem-It lifts sagging skin.

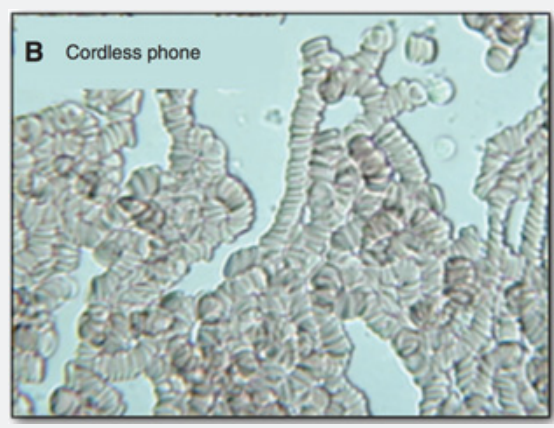

Figure 3: Clinical image of these red blood cells exposed to the dangers of Electro-Magnetic Fields or "EMFs radiations are clumped together? This is called a "Rouleaux" formation, linked with poor blood flow, oxygenation, and regeneration.

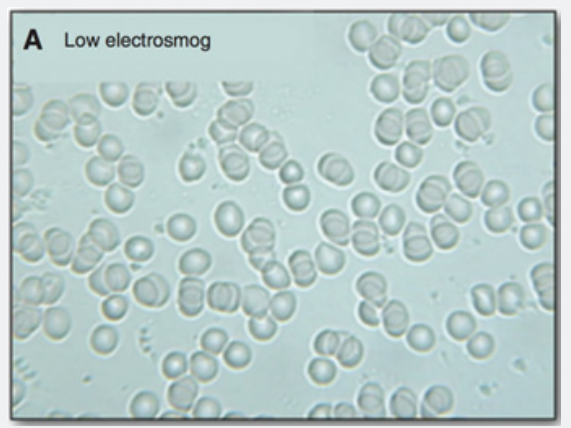

Figure 4: Clinical image of normal cells exposed to extremely low levels of Electro-Magnetic Fields. They are round, healthy-looking, and can circulate freely to perform their key functions. Application of Squalane nature's greatest moisturizer.

What's more, the researchers also reported that the women's crow's feet wrinkles has been significantly reduced and smoothed out. Pretty incredible results in a short amount of time! In a separate 3-week study, 106 volunteers used Majestem and reported these results
a) $86 \%$ of the participants reported softer skin
b) $83 \%$ reported more comfortable skin
c) $82 \%$ MAJESTEM $^{\mathrm{TM}}$ again
d) $79 \%$ of the participants they have satisfied overall

e) $\quad 74 \%$ that they felt their skin was more moisturized

f) $67 \%$ reported that their skin felt firmer and more toned Amazing results over just 3 weeks!

\section{Senestem - The Collagen Stimulator}

Senestem has an extract of Plantago lanceolata (Plantain), a perennial plant from Eurasia with oval, ribbed short-stemmed green leaves. Researcher indicates its collagen-synthesizing effects help

a) Reduce visible signs of aging and smooth the skin

b) Improve skin density and thickness

c) Brighten age-related pigment spots

In a placebo-controlled study, 56 women with visible signs of aging (including loose skin and pigmented age spots) applied a cream containing 2\% Senestem (the same amount in Ageless Glow) to their faces and the back of their hands twice daily for two months. Compared to the placebo group, in as little as one month, the researchers found that the participants using Senestem experienced

a) Significant improvements in skin firmness, thickness, and elasticity on the back of their hands

b) Significant smoothing of crow's feet wrinkles

c) Significant reductions in pigmented age spots on their hands, Next up in Ageless Glow has

Squalane Nature's Greatest Moisturizer, Squalene has oil produced naturally in the body. It's key to having supple, younglooking skin that has soft to the touch. However, squalene production decreases naturally with age, slowing down drastically after age thirty, resulting in dry, wrinkled skin. In a study published in the Journal of Dermatological Science, researchers from the Department of Dermatology at Juntendo University in Tokyo found that application of a squalene-based skin rejuvenator dramatically increased hydration and improved skin barrier function. This is why we added squalane to Ageless Glow; it's a super moisturizer that absorbs quickly without a greasy film, leaving your skin glowing and soft to the touch.

Sodium Hyaluronate The Wrinkle Eraser. Sodium Hyaluronate ( $\mathrm{SH}$ ) has been added to Ageless Glow ${ }^{\mathrm{TM}}$ because it has been shown to hydrate the skin and accelerate the repair of damaged skin. In fact, one gram of SH can hold up to $6 \mathrm{~L}$ of water! It soaks up moisture like a sponge. As a result, SH users often report that it "plumps" the appearance of wrinkles, leaving smooth skin behind [2].

\section{Conclusion}

This study showed impressive results with the natural ingredients found in Ageless Glow. Researcher know the ingredients work in studies and in the lab, and even better, the first round of «real world» feedback from volunteer, with rave 
reviews! «People have not seen in several years are telling I look GREAT! Researcher has only been using Ageless Glow for a couple of weeks!» «Ageless Glow has helped decrease wrinkles more than any other product. Researcher has used in the past and love that it is not greasy at all!».»It can see a big difference in my skin face, neck, hands, arms, and brown spots before long all wrinkles are going to be gone!» It has Zero connective tissue degradation [3]. It has significant reductions in skin sagging on the face and cheek bones as well as decreases in wrinkle depth and volume.

\section{References}

1. Rahul Hajare (2018) Pooling of lupus can catch early skin cancerous: Rapid Progression in DNA Damage. Clin Invest 8(2): 91-93.

2. Rahul Hajare (2018) Safe Sex: The True Principal Health? Medical Research and Clinical Case Reports. 1(2): 58-60.

3. Rahul H (2017) Early rising may be linked to mental health issues in institute of pharmaceutical science an observational study draws inference from a legal to cultural principles through independent variables. Biomed J Sci \& Tech Res 1(1): 1-2.

\section{Your next submission with Juniper Publishers will reach you the below assets}

- Quality Editorial service

- Swift Peer Review

- Reprints availability

- E-prints Service

- Manuscript Podcast for convenient understanding

- Global attainment for your research

- Manuscript accessibility in different formats ( Pdf, E-pub, Full Text, Audio)

- Unceasing customer service

Track the below URL for one-step submission https://juniperpublishers.com/online-submission.php 